\title{
What Is the Impact of Informal Entrepreneurship on Venture Capital Flows?
}

\author{
Eunice Santos ${ }^{1} \cdot$ Cristina I. Fernandes $^{1,2}$ (D) João J. Ferreira ${ }^{1} \cdot$ \\ Carla Azevedo Lobo ${ }^{3}$
}

Received: 22 June 2019 / Accepted: 27 October 2020 / Published online: 23 November 2020

(C) The Author(s) 2020

\begin{abstract}
There has been a diverse range of research on the factors enabling informal entrepreneurship as well as the means to avoid or to eradicate its incidence. Several researchers argued that venture capital and financial flows, in general, contribute to economic growth and development. There have also been observations of how the investor level of trust in institutions facilitates investment decisions. This trust comes into play at the level of informal entrepreneurship and the ability of governments to control this type of entrepreneurship. Given that a great deal of research on this subject focuses its analysis on developing countries, we have chosen to investigate the reality of European countries precisely because of the scarcity of studies on the effect of informal entrepreneurship in this context. Our research aims to assess how informal entrepreneurship effects on venture capital flows. We use aggregated data at country level collected from a variety of sources, including the World Bank, Organization for Cooperation and Development and World Economic Forum, between 2006 and 2015 and 23 countries in Europe, corresponding to 230 observations (panel no. balanced). Through econometric estimation, which took place according to methodologies based on multiple regression models for panel data, the results demonstrate how informal entrepreneurship has a negative moderating effect between GDP and venture cUKapital flows. We intend to contribute to a better understanding of the effect of informal entrepreneurship on the flows of venture capital.
\end{abstract}

Keywords Informal entrepreneurship · Venture capital · Economic development

\section{Introduction}

This current research seeks to evaluate the effect of informal entrepreneurship on venture capital flows. In recent years, and in opposition to the conventional literature in which

Cristina I. Fernandes

cristina.isabel.fernandes@ubi.pt

Extended author information available on the last page of the article 
entrepreneurs emerge as some kind of business heroes (Cannon 1991) or supermen and often portrayed as objects of desire (Berglund and Johansson 2007), another approach has emerged that considers other practical entrepreneurship experiences. One aspect incorporates the growing literature on the lunar side of entrepreneurship. This spans at least two sets of literature. One set focuses on the fact that individuals who engage in illegitimate activities also display both entrepreneurship (Armstrong 2005; Bruns et al. 2011; Karjanen 2011; de Jong et al. 2012; Smith and McElwee 2013) and the typical attributes of "entrepreneurs" (Gottschalk and Smith 2011; Bucur et al. 2012). The other set, which is the object of our study here, approaches informal entrepreneurship and recognizes how entrepreneurs sometimes operate entirely or partially in the informal economy (Aidis et al. 2006; Williams 2008, 2009a, b; Antonopoulos and Mitra 2009; Gurtoo and Williams 2009; Webb et al. 2009; Williams and Nadin 2011, 2012a, b, 2013).

In recent decades, the generalized processes of modernization, globalization and technological progress have made world economies increasingly dynamic and interconnected after having fostered the development of multinational companies. One of the leading measurements of multinational activities stems from levels of foreign direct investment (FDI), defined by the OECD as investments in companies in which investors hold at least $10 \%$ of the common shares, to establish a "lasting interest" in the host country and not only a long-term relationship but also influence over the respective company management (OECD 2008, 2012).

For Saetre (2003), entrepreneurs do not want only investors who contribute financially in the capital. For some entrepreneurs, it is not enough just to have investors who bring business experience; want investors with skills and experience relevant to their companies. Experienced investors and specific niche networks provide significant added value for companies. This added value qualifies as a form of capital itself (Fisher 1919). Over the past decade, there has been a growing interest in informal entrepreneurship and its effect on venture capital flows, both politically and academically (Martinez et al. 2015).

For most entrepreneurs, the demand for venture capital funding depends on formal institutions that function properly related to law and regulation (Martinez et al. 2015). Ramamurti (2003) describes this as an "institutional design challenge" requiring the right combination of substantive legal and regulatory rules, related legal and regulatory processes to apply them. Our research aims to assess how informal entrepreneurship effect on venture capital flows. This raises our research question: what is the effect of informal entrepreneurship on venture capital flows?

By implication, risk-adverse financing will flow to economies where formal institutions provide investors with greater protection, particularly when these investors are well-educated and technically oriented (Guler and Guillen 2010). Khoury et al. (2012) note that investors in more exposed environments often have to commit more resources to compensate for the likelihood of costly contractual transgressions and may instead choose not to invest. Zacharakis et al. (2007) conclude that venture capital markets in economies with higher levels of informal entrepreneurship encounter entrepreneurs facing greater challenges. Investors may feel that they are unable to rely on appropriate legal and regulatory institutional safeguards to protect the terms of their initial investment contracts from risks such as opportunistic renegotiation by creditors and local government. 
Our research contributes to the development of theory, practice and public policies of entrepreneurship across two important facets. Firstly, when we study the effect that the existence of informal entrepreneurship has on the venture capital flows, we convey the importance of the level of trust that investors need to perceive in the institutions in which they will invest their money. Informal entrepreneurship can be an inhibiting factor in these financial flows. Secondly, the majority of studies on informal entrepreneurship concentrate primarily on developing countries, even if not exclusively. The ILO (2012) reports that one in six (17\%) members of the global non-agriculture labour force engages in some form of informal sector entrepreneurship as their main form of employment. However, the percentage of the non-agricultural workforce involved in informal entrepreneurship varies across global regions: $26 \%$ in sub-Saharan Africa, $23 \%$ in Latin America and the Caribbean and 19\% in East Asia and Pacific, down to $11 \%$ in the Middle East and North Africa, 10\% in South Asia and 8.5\% in Europe and Central Asia.

In terms of participation in informal sector entrepreneurship in the 27 member states of the European Union (UE-27), analysis by the Eurobarometer 2007 survey no. 284 on the informal labour sector finds that 1 in 28 (almost $4 \%$ ) of the 26,659 adults interviewed reported some form of such entrepreneurship over the last 12 months, spending an average of $73 \mathrm{~h}$ on such work and earning an average of $€ 11.05$ /hour, producing an annual average income from informal entrepreneurship totalling $€ 806$. Almost three-quarters $(73 \%)$ of this autonomous informal labour takes place through close social relations (for example, parents, neighbours, friends, acquaintances and colleagues). A little over one-quarter $(27 \%)$ is at the behest of others, previously unknown persons and families. As far as we know, this research is the first to articulate the effect of informal entrepreneurship on venture capital, specifically in Europe, where the level of informality is considered relatively low.

Therefore, this problematic framework rarely gets approached in Europe and correspondingly justifying the importance of this study.

We thus share with other entrepreneurship researchers this interest in understanding whether and when financial flows to different countries become more likely to shift to financing commercial transactions, such as launching new businesses. Our research proposes informality as an alternative causal factor interlinked with the institutional, rather than the natural, environment prevailing in developed countries.

Our paper is structured as follows: in the following section, we present the literature review, in which we develop the relationship of informal entrepreneurship, GDP and financial flows (venture capital flows). Next, we present the methodology, the respective results and their discussion. Finally, we draw the conclusions, implications and future lines of research.

\section{Theoretical Underpinnings and Literature Review}

\section{Theoretical Underpinnings: Institutional Approach}

According to Scott (1995), the institutional environment of a country depends on relatively stable rules, social norms and cognitive structures that establish the 
conditions necessary for the occurrence of market transactions. Institutions classify as structures - with rules and regulations for their cultures, customs and traditions that ensure they operate as a society (Szyliowicz and Galvin, 2010). These structures form the logic that governs the taking of economic decisions and engagement in market activities (Yeung, 2002).

Hence, various researchers have defended that an appropriate institutional environment provides the necessary conditions for individuals to identify market opportunities, launch new activities, introduce innovations and new products and services as well as creating posts of employment (Baumol, 2002, Aparicio et al., 2016). Baumol (1990) defends how the quality of the institutional context influences the allocation of different types of entrepreneurship. Within a similar scope, North (1990) defines institutions as the rules of the game that guide the behaviours of individuals and provide a structure of incentives for actors, reducing transaction-related problems. Therefore, Boettke and Coyne (2009) maintain that institutions can facilitate economic, political and social interactions, fostering incentives for different courses of action and guiding the emergence of economic actors. When these rules are well-defined, opportunism declines, trust rises and there is greater recourse to long term contracts and thereby cutting transaction costs and fostering efficient institutional structures (Arias and Caballero, 2006).

Furthermore, low-quality institutions reduce the incentives to invest and hinder resources from getting allocated to more productive purposes (Knowles and Weatherson, 2006). Hence, researchers that adopt institutional theory establish a distinction between formal institutions (the laws and codified regulations) and informal institutions (norms, values and codes of conduct) and the informal sector, to portray entrepreneurs that operate outside of formal institutional boundaries but within the scope of informal institutions (Webb et al. 2009). Based on this institutional perspective, the tendency for entrepreneurs to operate in the informal sector stems from the asymmetry between the formal and informal institutions in a society.

The greater the incongruence between the formal and informal institutions, the greater the tendency for entrepreneurs to operate in the informal sector. The informal entrepreneurship has thus proven to be a constant problem both in the developing world and advanced economies such as in the European Union (EU). Ever since the 1970s, the processes of industrial downsizing and outsourcing have renewed the importance of small-scale companies that are more easily able to hide their business data than their larger counterparts.

Hence, as EU economies have become increasingly regulated, this has raised the costs of launching and running a business and effectively served to drive more companies and employees into the informal sector (OECD, 2015).

\section{Literature Review}

Rizvi et al. (2009) analyzed the effect of foreign direct investment (FDI) on employment opportunities. The data results suggest that GDP has a significant effect on the level of employment. Besides, FDI has no effect on job creation. A similar study was conducted by Nunnenkamp, Bremont and Waldkirch (2007), who found that FDI and the flow of venture capital flow depend on 
investor confidence in country structures, while FDI and venture capital flows provide employment. They conclude that employment growth will not occur as a spontaneous consequence of GDP growth, but rather of cooperation between policies and investor confidence.

The level of informality may shake this confidence in keeping with the extent to which transactions occur beyond the bureaucratic "gaze" and thus avoiding any regulatory control by the government (Hart 2007). Webb et al. (2009) appropriately define the domain of informality: whenever legal and illegal transactions are allowed, provided that they do not violate local social standards of acceptability. Thus, a hairdresser maybe informal if the government simply cannot observe and regulate it, but a lending business, precisely under the same conditions as the hairdresser's informality, would not be considered merely informal if the interest rates it charges are considered usury by community standards (Martinez et al. 2015).

Schneider and Enste (2002) explain informality in terms of economic and non-economic constraints. Institutions that are generally less regulated and prepared, and with fewer resources, encounter greater economic constraints than formalized institutions (Blades et al. 2011). However, other non-economic restrictions may also hinder the development of formal oversight and regulation of many business transactions. For example, fragmentation along linguistic, ethnic and/or religious lines may undermine the legitimacy of national government institutions and, therefore, compliance with their duties. Similarly, whenever a single party rules a particular country, laws and their application tend to become more arbitrary, for example, in countries of the former USSR and thus resulting in government institution legitimacy problems (Flodman-Becker 2004). We may furthermore add to this list the scope for governments to intentionally turn a blind eye to unregulated microenterprises to foster economic growth otherwise led by corporate entities (Kan 2000).

Thus, institutions remain subject to human design with all the constraints that shape human interactions (North 1990) but nevertheless establishing the rules of functioning for societies and still holding the capacity to uphold the rule of law (North 1990; Scott 1995). Indeed, for most entrepreneurs, the search for venture capital funding depends on formal institutions that function well about the legislation and regulation. Ramamurti (2003) describes this situation as involving institutional design challenges requiring a combination of certain substantive legal and regulatory rules.

In this context, it is thus hardly surprising that recent entrepreneurship research findings have documented links between higher levels of entrepreneurial activity, including more risk-funding activities, and stronger legal and regulatory institutions and higher levels of institutional formalization ( $\mathrm{Li}$ and Zahra 2012). This effectiveness is important for formal institutions implementing fiscal policies and executing contracts (Lerner 2009) as well as to legal practitioners, politicians (Khoury et al. 2012) and financial markets in general (Straub 2005). By implication, lower levels of high-risk financing flow to economies where formal institutions endow investors with less protection, particularly when these investors are well-educated and technically oriented (Guler and Guillen 2010). 
Khoury et al. (2012) note that investors in less formalized environments often have to commit more resources to compensate for costly contractual transgressions and therefore may instead choose not to invest. Zacharakis et al. (2007) conclude that venture capital markets approach lower levels of national development and economic growth as also incurring major challenges for entrepreneurs and venture capital investors. Thus, whenever informality denotes the absence of important legal and regulatory institutional capacities, then informality also undermines the critical assurances necessary to the creation and transfer of venture capital to new and growing firms (Martinez et al. 2015).

We may thus formulate our research hypothesis:

H1: Informal entrepreneurship has a negative effect on venture capital flows.

\section{Methodology}

\section{Data}

The data applied stems from statistics aggregated at the national level after collection from various sources, specifically the World Bank (WB), the Organisation for Economic Cooperation and Development (OECD), the Global Entrepreneurship Monitor (GEM), for the period between 2006 and 2015, and World Economic Forum between 2007 and 2016.

For 23 European states, corresponding to a total of 230 observations (balanced panel). Table 1 shows an overview of the variables used in the study.

\section{Measures}

\section{Dependent Variable}

The dependent variable of this study refers to the availability of venture capital. Venture capital flow data were obtained from the World Economic Forum and correspond to the average responses to a question from the Global Competitiveness Index study in which a panel of country managers is asked about the difficulty of securing start-ups and innovative projects with risk. The answer corresponds to a Likert scale of 1 to 7 , with higher scores indicating greater funding through venture capital.

\section{Predictive Variables}

Control Variables The data of the predictor variables were used to control variables such as size, namely, GDP (in logarithm), GDP growth (\%), GDP per capita (in logarithm), investment (gross fixed capital formation in\% of GDP), inflation (\%) and foreign direct investment (FDI, inflows, \% of GDP) as an external factor.

Informal Entrepreneurship Variable This study applied informal entrepreneurship as the dependent variable corresponding to the rate of informal new business startups per 100 adult age persons. As informal entrepreneurs are not subject to direct measurement, we adopted the Autio and $\mathrm{Fu}$ (2015) approach to estimating informal entrepreneurship in this study. 


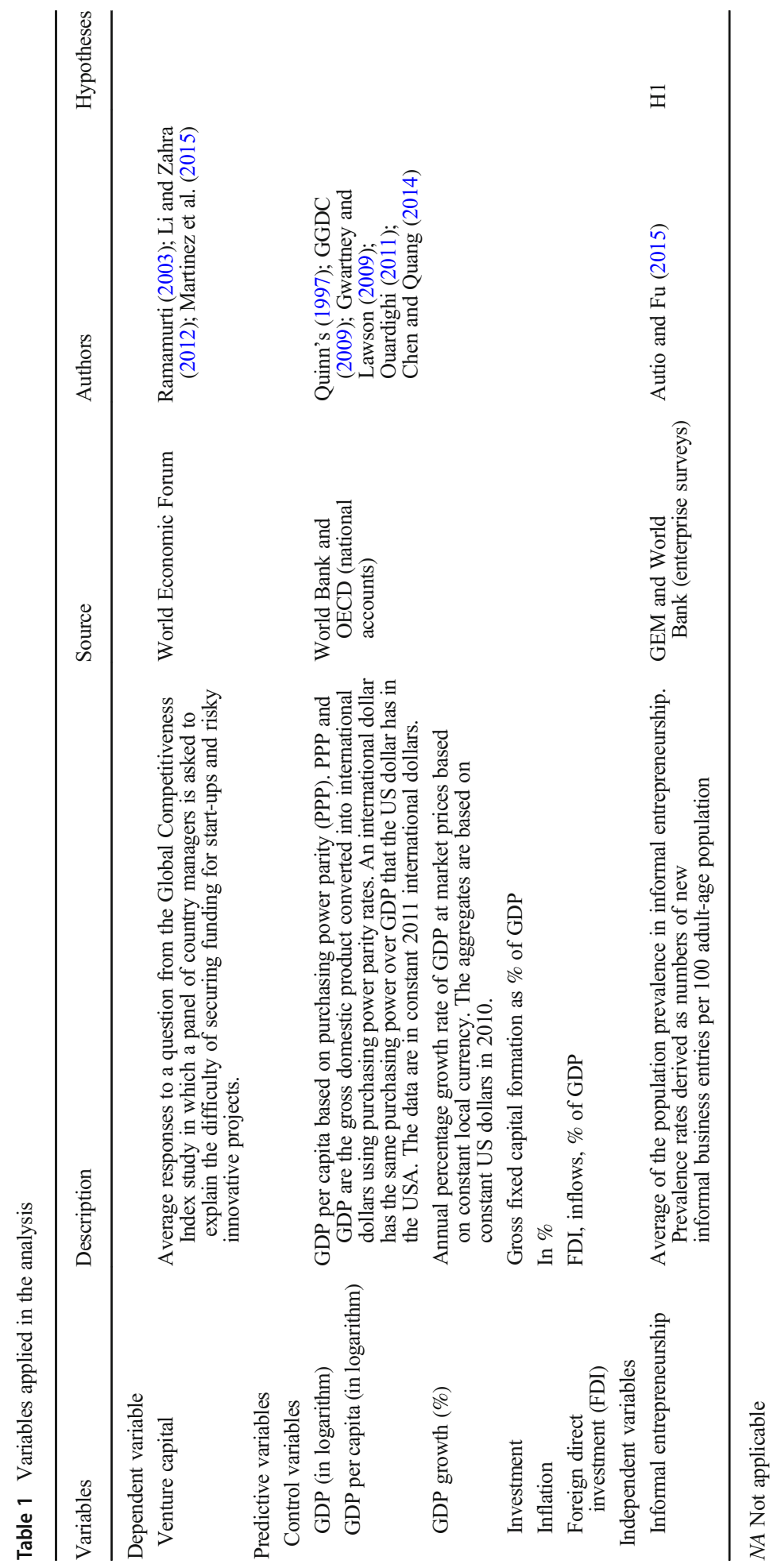


Hence, we applied the following simultaneous equations to the GEM collected data:

$$
\left\{\begin{array}{c}
y_{\text {new }}=x \times\left(0.5+\sum_{t=1}^{3} e^{-\lambda t}\right) \\
y_{\text {established }}=\int_{3}^{+\infty} e^{-\lambda t} d t
\end{array}\right.
$$

in which $y_{\text {new }}$ is the incidence of new entrepreneurs with these new business owners paying out wages, bonuses or any other payments to either their owners or employees over a period of between 3 and 42 months. $y_{\text {established }}$ reflects the incidence rate for established entrepreneurs paying out wages and salaries for a period of over 42 months. $x$ corresponds to the new entrepreneur entrance rate and with $\lambda$ the parameter for the exponential distribution of the survival rate.

We then normalized the new entrepreneur estimated entrance rate by dividing it by the GEM estimate for the average number of team members launching the new businesses to result in an estimate for the annual entrance rate of every type of new business, both registered and non-registered. Finally, to determine the entrance rate for informal businesses (the number of informal business per 100 adult individuals), we subtracted the annual entrance rate for all new types of business from the World Bank estimate for the entrance rate of newly registered businesses. This measure then represents the level of informal entrepreneurship in each sample country.

\section{Data Analysis}

The aim was to determine the effect and the moderating effect of informal entrepreneurship, as well as internal and external control variables in the venture capital flows. The estimated equation presents the following general form:

$$
\text { Venture }_{i t}=f\left(\text { InfEnt }_{i t-1}, \text { VarControlo }_{i t-1}, \operatorname{InfEnt}_{i t-1} \times \operatorname{VarControlo}_{i t-1}\right)
$$

where $i$ are the countries $(1,2, \ldots, 23)$ and $t$ the various years $(2007, \ldots, 2016)$. It should be noted that the availability of venture capital flows in year $t$ is dependent on the other variables in year $t-1$ (previous year). The formal regression analysis will examine the validity of these relationships, with the econometric analysis being based on multiple regression models for panel data for the 23 countries as a whole, with baseline estimates being made on random-effects models. Thus, the following econometric models were estimated:

(1) Venture $_{i t}=\alpha_{0}+\alpha_{1}$ InfEnt $_{i t-1}$

(2) Venture $_{i t}=\alpha_{0}+\alpha_{1} \mathrm{Ln}_{-} \mathrm{GDP}_{i t-1}+\alpha_{2} \mathrm{GDP}_{-} \mathrm{GR}_{i t-1}+\alpha_{3} \mathrm{GDP}_{-} \mathrm{PC}_{i t-1}+$ $\alpha_{4} \mathrm{GFCF}_{i t-1}+\alpha_{5} \mathrm{INF}_{i t-1}$

(3) Venture $_{i t}=\alpha_{0}+\alpha_{1} \mathrm{FDI}_{i t-1}$

(4) Venture $_{i t}=\alpha_{0}+\alpha_{1} \mathrm{InfEnt}_{i t-1}+\alpha_{2} \mathrm{Ln}_{-} \mathrm{GDP}_{i t-1}+\alpha_{3} \mathrm{GDP}_{-} \mathrm{GR}_{i t-1}+\alpha_{4} \mathrm{GDP}$ $\mathrm{PC}_{i t-1}+\alpha_{5} \mathrm{GFCF}_{i t-1}+\alpha_{6} \mathrm{INF}_{i t-1}+\alpha_{7} \mathrm{FDI}_{i t-1}+\alpha_{8} \mathrm{Ln}_{-} \mathrm{GDP}_{i t-1} \times \operatorname{InfEnt}_{i t-1}+$ $\alpha_{9} \mathrm{GDP}_{-} \mathrm{GR}_{i t-1} \times \mathrm{InfEnt}_{i t-1}+\alpha_{10} \mathrm{GDP}_{-} \mathrm{PC}_{i t-1} \times \mathrm{InfEnt}_{i t-1}+\alpha_{11} \mathrm{GFCF}_{i t-1} \times$ InfEnt $_{i t-1}+\alpha_{12} \mathrm{INF}_{i t-1} \times$ InfEnt $_{i t-1}+\alpha_{13} \overline{\mathrm{FDI}}_{i t-1} \times \mathrm{InfEnt}_{i t-1}$ 
In all the estimations, the existence of multicollinearity between the variance inflation factor (VIF) was evaluated, as well as robust standard errors were estimated for the coefficients, to eliminate the possible problems of heteroscedasticity.

Data were processed using STATA software version 12.0 (StataCorp LP, TX, USA).

\section{Results and Discussion}

\section{Descriptive Statistics}

Table 2 shows the descriptive statistics and correlation coefficients for the endogenous variables used in the econometric modelling as well as the VIFs, noting that there were no variables with multicollinearity effects $(\mathrm{VIF}<5)$.

\section{Econometric Modelling}

Table 3 presents the results allusive to the different models of estimated random effects. Regarding the control variables, the results show that per capita GDP (Ln_PIB_PC) have a statistically significant positive influence on the availability of venture capital (model $4 \beta=0.368 ; p<0.01$ ), as well as gross formation of fixed capital (model $2 \beta=$ $0.073, p<0.01$, model $4 \beta=0.082, p<0.01$ ). Thus, the greater the value of GDP per capita, the greater will be the availability of venture capital flows and gross fixed capital formation. A well-functioning legal system is a key factor that defines an economically free society, in which everyone contributes to a greater volume of capital flows and greater growth in the economy (Berggren 2003; Metwally 2004).

The range of incentives and the facilitation of exchange controls and legal and bureaucratic procedures may drive an expansion of exports susceptible to boosting gross domestic product and furthermore generating greater prior and direct investments. The economic policies able to improve an economy's growth include voluntary exchanges, free competition and the protection of people and goods, which all directly effect on the economic growth functions mentioned above with these correspondingly critical determinants of economic freedom (Gwartney and Lawson 2009; Sayari et al. 2018). In this sense, significant achievements in terms of economic growth require still more democracy and economic freedom as economic success brings with it more education, awareness, self-esteem and personal choices (Helliwell 1994; De Haan and Sturm 2000; Doucouliagos and Ulubaşoğlu 2008).

However, this result may not be achieved equally across all economic sectors because of the nature of these same sectors and the skills they require. Economic success can empower some individuals who consequently require less government intervention (Krueger 1990). However, determined and successful people must demand and gain access to a more effective legal system. Economic success is also able to attract foreign interest, which subsequently reinforces the choices for economic freedom (Paldam, 2003). Thus, greater economic development receives support from the greater levels of formality that provide greater confidence and trust in the respective national institutions and thus fostering higher inflows of money, more specifically of venture capital flows (Ayal and Karras 1998; Carlsson and Lundström 2002; Mahmood et al. 2010; Paldam, 2003; Pääkkönen 2010; Akin et al. 2014; Martinez et al. 2015). 


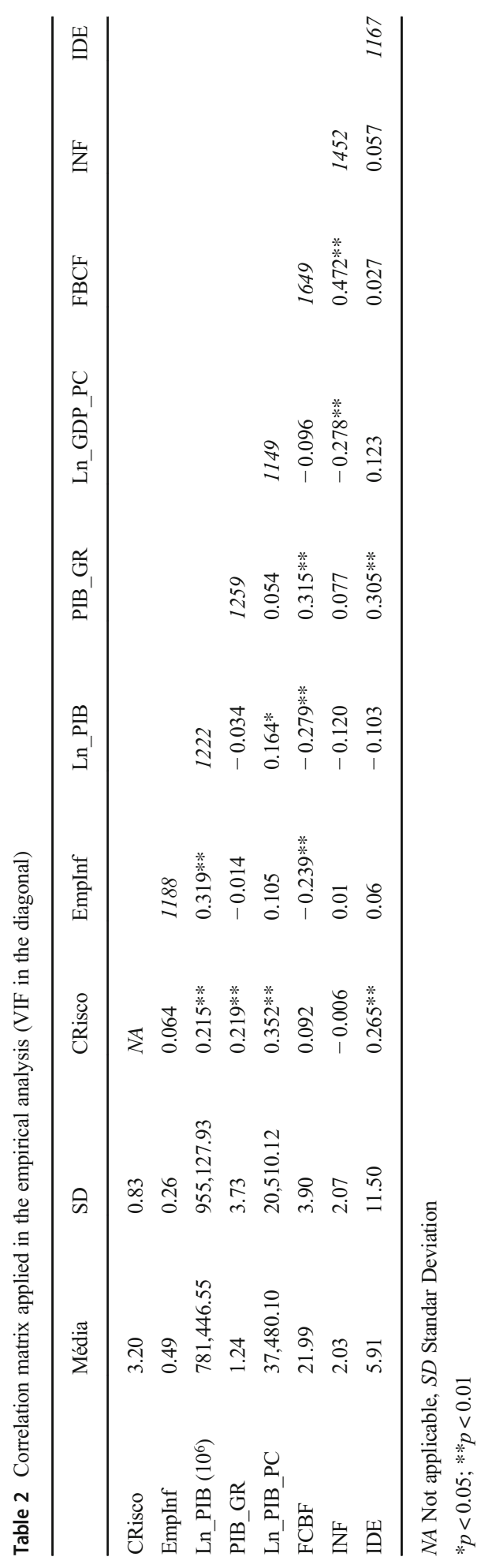


Table 3 Coefficients estimated for the econometric models (standard errors)

\begin{tabular}{|c|c|c|c|c|}
\hline & 1 & 2 & 3 & 4 \\
\hline InfEnt & $-0.128(0.513)$ & & & 1.627 (1.337) \\
\hline Ln_GDP & & $0.002(0.015)$ & & $0.000(0.000)$ \\
\hline GDP_GR & & $0.081(0.075)$ & & $-0.023(0.137)$ \\
\hline Ln_GDP_PC & & $0.096(0.072)$ & & $0.368(0.142)^{* *}$ \\
\hline GDP_PC_GR & & $-0.043(0.073)$ & & $0.025(0.132)$ \\
\hline GFCF & & $0.073(0.013)^{* *}$ & & $0.082(0.028)^{* *}$ \\
\hline INF & & $-0.02(0.018)$ & & $-0.075(0.045)^{\ddagger}$ \\
\hline FDI & & & $0.015(0.004)$ & $0.013(0.014)$ \\
\hline Ln_GDP $\times$ InfEnt & & & & $0.000(0.000)$ \\
\hline GDP_GR $\times$ InfEnt & & & & $0.229(0.26)$ \\
\hline Ln_GDP_PC $\times$ InfEnt & & & & $-0.055(0.025)^{* *}$ \\
\hline GDP_PC_GR $\times$ InfEnt & & & & $-0.162(0.251)$ \\
\hline $\mathrm{GFCF} \times \mathrm{InfEnt}$ & & & & $-0.01(0.053)$ \\
\hline $\mathrm{INF} \times$ InfEnt & & & & $0.107(0.086)$ \\
\hline FDI $\times$ InfEnt & & & & $-0.008(0.023)$ \\
\hline$R^{2}$ & $1.0 \%$ & $35.2 \%$ & $7.7 \%$ & $38.3 \%$ \\
\hline Wald $\chi^{2}$ & 0.06 & $8.32 * *$ & $6.57 * *$ & $9.17 * *$ \\
\hline
\end{tabular}

${ }^{\dagger} p<0.10 ;{ }^{*} p<0.05 ; * * p<0.01$.

Similarly, the existence of a moderating effect of informal entrepreneurship on the influence of GDP per capita on the availability of venture capital (Ln_GDP_PC xInfEnt) was observed, in that the higher the informal entrepreneurship, the lower the effect of GDP per capita on venture capital flows availability (model $4 \beta=-0.055, p<0.01$ ).

In this way, we find that, in Europe, we cannot verify a direct effect of informal entrepreneurship on venture capital. However, we found a negative moderating effect between GDP and venture capital flows. We thus partially support our H1: informal entrepreneurship has a negative in venture capital. De Gregorio (1992) reported a positive effect of capital flows on economic growth. In turn, Blomstrom et al. (1994) found that capital flows return a significant and positive influence on economic growth even while this influence rises in keeping with the respective level of national development.

Borenzstein et al. (1998) identify how venture capital flows constitute an important vehicle for technology transferable to contribute towards economic growth but return a still greater effect on the level of human capital prevailing in the host economy. Campos and Kinoshita (2002) examine the effects of financial flows on economic growth in the 1990-1998 period for 25 Central and Eastern European countries and transition economies of the former Soviet Union. Their key results indicate how these flows drove a significant and positive effect on the economic growth of each selected country. Chowdhury and Mavrotas (2003), furthermore, found a causal relationship between GDP and financial flows, i.e. the higher the GDP, the greater the financial flows. They also argue that the higher level of economic development drives away informal entrepreneurship (Martinez et al. 2015). 
Interlinked with these considerations, institutional theory and the trust of individuals in institutions certainly emerge as core issues. Formal institutions correspondingly provide a structure for the trust that entrepreneurs need when embarking on business ventures. This furthermore facilitates the perceptions of business opportunities and influencing their number as well as their characteristics (Verheul et al., 2002). This results in an increase in the levels of entrepreneurial activities and a rise in venture capital flows (Levie and Autio, 2008). In this sense, an environment with a transparent legal system and clearly defined property rights mitigates against the risks taken by actors that provide resources to entrepreneurs (Estrin et al., 2013a).

This similarly eases access to financing, generally a key factor for the launch and growth of new businesses (Rajan and Zingales, 1998). As a consequence, the more developed formal institutions also foster risk capital investment, for example (Sobel, 2008; Li and Zahra 2012), an especially relevant alternative for financing projects in highly uncertain contexts but with high growth potential (Bowen and De Clercq, 2008). Furthermore, Anokhin and Schulze (2009) also defend how controlling corruption boosts confidence in institutions and markets and ensures a greater probability that entrepreneurs gain a proportion of the rewards susceptible to encouraging further entrepreneurship and innovations. This collectively amounts to a synonym for highquality economic institutions.

Thus, the trust and confidence that investors have in the countries to which they invest their money are crucial if financial flows are to occur. Informality, as we have said, removes this confidence. As we have also shown that informality has a negative moderating effect on GDP (level of economic development) and venture capital flows.

\section{Conclusions, Implications and Future Lines of Research}

The objective of our investigation was to determine the effect of informal entrepreneurship on the availability of venture capital flows and answer our research question: "what is the effect of informal entrepreneurship on venture capital flows?"

We conclude that the higher the value of GDP per capita the greater, the availability of venture capital flows and gross fixed capital formation. As we also concluded that, in Europe, we cannot verify a direct effect of informal entrepreneurship on venture capital. However, we observed a negative moderating effect of informal entrepreneurship on GDP and venture capital flows.

Informality is a double-edged sword. On the one hand, it allows market participants to operate without due accountability to the authorities while also hampering their access to government protection under relevant legal and regulatory provisions. There are a variety of means of overcoming the resulting institutional gaps (Khanna and Palepu 2000), including private agreements between individuals in which nongovernmental third parties, such as companies, professional or industrial associations, community or even illegal groups (but not illegitimate) (Webb et al. 2009) secure implementation.

In this sense, institutional theory can help us in explaining the negative effect of informality on the availability of venture capital flows. Transaction cost theory also contributes to understanding the positive effect of GDP on financial flows. According to Bucheli et al. (2010), the descriptive goal of transaction cost theory involves 
comparing the long-term costs of producing and exchanging goods and services in a market regime with the costs under alternative regimes.

Similarly, trust in institutions also influences investor understanding of the transaction costs of these financial flows in countries with higher levels of informality. We demonstrate how the institutional structure may influence venture capital flows. The existence of mechanisms that imposes reliable restrictions and the appropriate codes of conduct by the government that encourage and compel state employees to comply with the rules and regulations will eventually effect on enhanced growth in venture capital flows. Well-planned and implemented public institutions protect property, human rights and political liberties thereby nurturing the participation of citizens in economic life. Attention to these relationships, therefore, holds importance within the framework of better understanding the effects of political and economic institutions on the different forms of entrepreneurship.

Our results thus contribute to knowledge about the impact of informal entrepreneurship (contributing to less trust in institutions) in GDP and access to venture capital flows, in European countries. The lower the trust in institutions, the lower the level of informality, the lower the interest of investors in companies in these countries. This situation has a negative effect on the level of economic development since it is argued that the higher the level of financial flows, the greater the development and economic growth of the country (Berggren 2003; Metwally 2004).

Our findings are important for academic research at the level of informal entrepreneurship, which has so far largely been silent as regards its effect on financial flows. When these studies are carried out, they are essentially devoted to the study of multinationals (Kim and Li 2012; Webb et al. 2010). We have identified that investors observe not only the prevailing national level of development but also the lack of confidence in institutions, observed by the level of informal entrepreneurship, which generates a negative effect on their investment decisions even if only returning a moderating effect.

We demonstrate in theory and then, empirically, when the level of confidence (observed by entrepreneurship informs) has effects on remittances of financial flows, specifically on venture capital. We believe that our conclusions are important not only for the investigation of informal entrepreneurship but also for research in the area of economic development where debates continue to focus on whether and how financial flows contribute to the economic development conducted by enterprises (Yang 2011).

Our findings complement, rather than challenge, research findings that advocate the importance of institutional strengthening in European countries, particularly institutional strengthening that is able to attract entrepreneurs ( $\mathrm{Li}$ and Zahra 2012) and venture capitalists (Guler and Guillen 2010). However, we may constructively challenge an assumption commonly accepted by many in the field of entrepreneurship; venture capital exists because of the structures and rules of capital markets (Zider 1998).

Our research leads to relevant implications for practitioners and policymakers alike. Organizations such as banks, money transfer organizations and other international financial institutions should analyze how, and to what extent and for what purpose, there are external remittances returned to their countries. Policymakers in international organizations such as the World Bank (Ratha 2003), national agencies (Hasan and Chalmers 2008), and nongovernmental organizations such as the Global Entrepreneurship Monitor (Bosma and Levie 2010) also need to better understand when policies for 
investment and economic development are more likely to succeed. They might also correspondingly consider in greater depth the importance of these transnational actors in transfer financial resources and ideas that then diffuse through informal sectors.

Our findings are thus important for management-related initiatives and policies designed to engage the world's poorest people in business-based economic opportunities.

All investigations have limitations, and ours is no exception. The most critical limitation we point out is the fact that research has been carried out in developed countries. We know that these have characteristics of developing countries, where informal entrepreneurship proliferates. Therefore, in the future, it will be essential to carry out this research in the comparison between developed and developing countries. Another limitation that can be overcome with future studies is related to the nonsignificant differences found among the countries under study. In future research, we suggest an analysis of the impact of informal entrepreneurship on venture capital flows within each country individually, and the inclusion of other measurement measures may be relevant further to deepen this theme for the scientific and business community.

Funding This work is supported by FEDER funds from COMPETE 2020 and Portuguese funds-PORTUGAL 2020. Project IEcPBI-Interactive Ecosystem for Portuguese Business Internationalization-POCI-01-0145-FEDER-032139.

Open Access This article is licensed under a Creative Commons Attribution 4.0 International License, which permits use, sharing, adaptation, distribution and reproduction in any medium or format, as long as you give appropriate credit to the original author(s) and the source, provide a link to the Creative Commons licence, and indicate if changes were made. The images or other third party material in this article are included in the article's Creative Commons licence, unless indicated otherwise in a credit line to the material. If material is not included in the article's Creative Commons licence and your intended use is not permitted by statutory regulation or exceeds the permitted use, you will need to obtain permission directly from the copyright holder. To view a copy of this licence, visit http://creativecommons.org/licenses/by/4.0/.

\section{References}

Aidis, R., Welter, F., Smallbone, D., \& Isakova, N. (2006). Female entrepreneurship in transition economies: the case of Lithuania and Ukraine. Feminist Economics, 13(2), 157-183.

Akin, C. S., Aytun, C., \& Aktakas, B. G. (2014). The impact of economic freedom upon economic growth: an application on different income groups. Asian Economic Finance Review, 4(8), 1024-1039.

Anokhin, S., \& Schulze, W. S. (2009). Entrepreneurship, innovation, and corruption. Journal of Business Venturing, 24(5), 465-476.

Antonopoulos, G. A., \& Mitra, J. (2009). The hidden enterprise of bootlegging cigarettes out of Greece: two schemes of illegal entrepreneurship. Journal of Small Business and Entrepreneurship, 22(1), 1-8.

Aparicio, S., Urbano, D., \& Audretsch, D. (2016). Institutional factors, opportunity entrepreneurship and economic growth: panel data evidence. Technological Forecasting and Social Change, 102, 45-61. https://doi.org/10.1063/1.2756072.

Arias, X.C., \& Caballero, G. (2006). El retorno de las instituciones y lateoría de política económica. Netbibl. Armstrong, P. (2005). Critique of entrepreneurship: people and policy. Basingstoke: Palgrave Macmillan.

Autio, E., \& Fu, K. (2015). Economic and political institutions and entry into formal and informal entrepreneurship. Asia Pacific Journal of Management, 32(1, SI), 67-94.

Ayal, E. B., \& Karras, G. (1998). Components of economic freedom and growth: an empirical study. Journal of Development Areas, 32(3), 327. 
Baumol, W. J. (1990). Entrepreneurship: productive, unproductive, and destructive. Journal of Political Economy, 98(5), 893-921.

Baumol, W. J. (2002). The free-market innovation machine: Analyzing the growth miracle of capitalism. Princeton, NJ: Princeton University Press.

Berggren, N. (2003). The benefits of economic freedom. Independent Review, 8(2), 193-211.

Berglund, K., \& Johansson, A. W. (2007). Constructions of entrepreneurship: a discourse analysis of academic publications. Journal of Enterprising Communities, 1(1), 77-102.

Blades, D., Ferreira, F., \& Lugo, M. A. (2011). The informal economy in developing countries: an introduction. Review of Income and Wealth, 57(Special Issue), S1-S7.

Blomstrom, M., Lipsey, R. E., \& Zejan, M. (1994). What explains developing country growth. (p. 4132) Cambridge, MA: NBER4132.

Boettke, P. J., \& Coyne, C. J. (2009). Context matters: institutions and entrepreneurship. Foundations and Trends in Entrepreneurship, 5(3), 135-209.

Borenzstein, E., De Gregorio, J., \& Lee, J. W. (1998). How does foreign direct investment affect economic growth? Journal of International Economics, 45, 115-135.

Bosma, N., \& Levie, J. (2010). Global entrepreneurship monitor 2009 global report. Global Entrepreneurship Research Association and Global Entrepreneurship Monitor. Utrecht: Utrecht University.

Bowen, H., \& De Clercq, D. (2008). Institutional context and the allocation of entrepreneurial effort. Journal of International Business Studies, 39(4), 747-767.

Bruns, B., Miggelbrink, J., \& Müller, K. (2011). Smuggling and small-scale trade as part of informal economic practices: empirical findings from the Eastern external EU border. International Journal of Sociology and Social Policy, 31(11/12), 664-680.

Bucheli, M., Mahoney, J. T., and Vaaler, P. M. (2010). Chandler's living history: the visible hand of vertical integration in nineteenth century America viewed under a twenty-first century 48.

Bucur, D., Pantea, M., \& Dan, L. A. (2012). Profit criminal entrepreneurship. Journal of Criminal Investigation, 5(2), 19-39.

Campos, N. F., and Kinoshita, Y. (2002). Foreign direct investment as technology transferred: some panel evidence from the transition economies.Center for Economic Policy Research. Discussion Paper No. 3417.

Cannon, T. (1991). Enterprise: creation, development and growth. Oxford: Butterworth-Heinemann.

Carlsson, F., \& Lundström, S. (2002). Economic freedom and growth: decomposing the effects. Public Choice, 112(3), 335-344.

Chen, J., \& Quang, T. (2014). The impact of international financial integration on economic growth: new evidence on threshold effects. Economic Modelling, 42, 475-489.

Chowdhury, A., and Mavrotas, G. (2003). Foreign direct investment and growth: what causes what?. Department of Economics, Marquette University, USA, World Institute Development Economic Research/United Nations University.

De Gregorio, J. (1992). Economic growth in Latin America. Journal of Development Economics, 39, $59-84$.

De Haan, J., \& Sturm, J. E. (2000). On the relationship between economic freedom and economic growth. European Journal of Political Economy, 16(2), 215-241.

de Jong, L., Tu, P. A., \& van Ees, H. (2012). Which entrepreneurs bribe and what do they get from it? Exploratory evidence from Vietnam. Entrepreneurship Theory and Practice, 36(2), 323-345.

Doucouliagos, H., \& Ulubaşoğlu, M. A. (2008). Democracy and economic growth: a meta-analysis. Journal of Political Science, 52(1), 61-83.

Estrin, S., Korosteleva, J., \& Mickiewicz, T. (2013). Which institutions encourage entrepreneurial growth aspirations? Journal of Business Venturing, 28(4), 564-580.

Fisher, I. (1919). The nature of capital and income. New York: The Macmillan Company.

Flodman-Becker, K. (2004). The informal economy. Stockholm: Swedish International Development Cooperation Agency.

GGDC. (2009). The conference board total economy database, Groningen growth and development centre. http://www.conference-board.org/economics.

Gottschalk, P., \& Smith, R. (2011). Criminal entrepreneurship, white-collar criminality and neutralization theory. Journal of Enterprising Communities, 5(4), 283-296.

Guler, I., \& Guillen, M. (2010). Institutions and the internationalization of US venture capital firms. Journal of International Business Studies, 41, 185-205.

Gurtoo, A., \& Williams, C. C. (2009). Entrepreneurship and the informal sector: some lessons from India. International Journal of Entrepreneurship and Innovation, 10(1), 55-62. 
Gwartney, J., \& Lawson, R. (2009). Economic freedom of the world: 2009 annual report. Vancouver: The Fraser Institute Data retrieved from www.freetheworld.com.

Hart, K. (2007). Bureaucratic form and the informal economy. In B. Guha-Khasnobis, R. Kanbur, \& E. Ostrom (Eds.), Linking the formal and informal economy (pp. 21-35). New York: Oxford University Press.

Hasan, M., \& Chalmers, C. (2008). UK Somali remittances survey. London: Department for International Development Available electronically on January 1, 2014 at: http://www.diaspora-centre.org/DOCS/UK_ Somali_Remittan.pdf.

Helliwell, J. F. (1994). Empirical linkages between democracy and economic growth. British Journal of Political Science, 24(2), 225-248.

Kan, K. (2000). Informal capital sources and household investment: evidence from Taiwan. Journal of Development Economics, 62, 209-232.

Karjanen, D. (2011). Tracing informal and illicit flows after socialism: a micro-commodity supply chain analysis in the Slovak Republic. International Journal of Sociology and Social Policy, 31(11/12), 648663.

Khanna, T., \& Palepu, K. (2000). Is group affiliation profitable in emerging markets? An analysis of diversified Indian business groups. Journal of Finance, 55, 867-891.

Khoury, T., Junkunc, M., \& Mingo, S. (2012). Navigating political hazard risks and legal system quality: venture capital investments in Latin America. Journal of Management, 41(3), 808-840.

Kim, P., \& Li, M. (2012). Injecting demand through spillovers: foreign direct investment, domestic socioeconomic conditions, and host-country entrepreneurial activity. Journal of Business Venturing, 29, 210231.

Knowles, S. \& Weatherson, C. (2006). Informal Institutions and cross-country income differences. University of Otago, Dunedin, Economics Discussion Papers \# 0604.

Krueger, A. O. (1990). Government failures in development. Journal of Economic Perspectives, 4(3), 9-23.

Lerner, J. (2009). Boulevard of broken dreams. Princeton: Princeton University Press.

Levie, J., \& Autio, E. (2008). A theoretical grounding and test of the GEM model. Small Business Economics, 31(3), 235-263.

Li, Y., \& Zahra, S. (2012). Formal institutions, culture, and venture capital activity: a cross-country analysis. Journal of Business Venturing, 27, 95-111.

Mahmood, K., Azid, T., Chaudhry, I. S., \& Faridi, M. Z. (2010). Impact of economic freedom on economic growth: the case of some selected SAARC member countries. International Research Journal of Finance and Economics, 52(52).

Martinez, C., Cummings, M., \& Vaaler, P. (2015). Economic informality and the venture funding impact of migrant remittances to developing countries. Journal of Business Venturing, 30(4), 526-545.

Metwally, M. M. (2004). Impact of EU, FDI on economic growth in Middle Eastern countries. European Business Review, 16(4), 381-389.

North, D. C. (1990). Institutions, institutional change and economic performance. Cambridge: Cambridge University Press.

Nunnenkamp, Bremont, \& Waldkirch (2007). FDI in Mexico: An empirical assessment of employment effects. (Kiel Working Paper No. 1328).

OCDE. (2015). Policy brief on informal. Entrepreneurship entrepreneurial activities in Europe. Luxembourg: Publications Office of the European Union, 2015

OECD (2008). OECD benchmark definition of foreign direct investment - fourth edition. OECD Publishing. https://www.oecd.org/daf/inv/investmentstatisticsandanalysis/40193734.pdf. Last access: 05/03/2017.

OECD. (2012). Reducing opportunities for tax non-compliance in the underground economy. Paris: OECD.

Ouardighi, J. (2011). Pro-development economic growth and international income mobility: evidence worldwide. International Economics, 128, 77-96.

Pääkkönen, J. (2010). Economic freedom as driver of growth in transition. Economic System, 34(4), 469-479.

Paldam, M. (2003). Economic freedom and the success of the Asian tigers: an essay on controversy. European Journal of Political Economy, 19(3), 453-477.

Quinn, D. (1997). The correlates of change in international financial regulation. The American Political Science Review, 91, 531-551.

Rajan, R., \& Zingales, L. (1998). Financial dependence and growth. American Economic Review, 88, 559586.

Ramamurti, R. (2003). Can governments make credible promises: insights from infrastructure projects in emerging economies. Journal of International Management, 9, 253-269.

Ratha, D. (2003). Workers' remittances: an important and stable source of external development finance. Global Development Finance. Washington, DC, World Bank, 157-175. 
Rizvi, S., Abbas, Z., \& Nishat. (2009). The impact of foreign direct investment on employment opportunities. The Pakistan Development Review., 48(4), 841-851.

Saetre, A. (2003). Entrepreneurial perspectives on informal venture capital. Venture Capital: An International Journal of Entrepreneurial Finance, 5(1), 71-94.

Santos, E., Fernandes, C., \& Ferreira, J. (2019). The role of political and economic institutions in informal entrepreneurship. World Journal of Entrepreneurship, Management and Sustainable Development, 15(4), 366-383.

Sayari, N., Sari, R., \& Hammoudeh, S. (2018). The impact of value added components of GDP and FDI on economic freedom in Europe. Economic Systems, 42(2), 282-294.

Schneider, F., \& Enste, D. (2002). The shadow economy. Cambridge: Cambridge University Press.

Scott, R. (1995). Institutions and organizations. Thousand Oaks: Sage Publications.

Smith, R., \& McElwee, G. (2013). Confronting social constructions of rural criminality: a case story on "illegal pluriactivity" in the farming community. Sociologia Ruralis, 53(1), 112-134.

Sobel, R. (2008). Testing Baumol: Institutional quality and the productivity of entrepreneurship. Journal of Business Venturing, 23(6), 641-655.

Straub, S. (2005). Informal sector: the credit market channel. Journal of Development Economics, 78, 299321.

Szyliowicz, D., \& Galvin, T. (2010). Applying broader strokes: Extending institutional perspectives and agendas for international entrepreneurship research. International Business Review, 19(4), 317-332. https://doi.org/10.1016/j.ibusrev.2010.01.002.

Verheul, I., Wennekers, S., Audretsch, D., \& Thurik, R. (2002). An eclectic theory of entrepreneurship: Policies, institutions and culture. In D. Audretsch, R. Thurik, I. Verheul, \& S. Wennekers (Eds.), Entrepreneurship: determinants and policy in a European-US comparison. Boston: Kluwer Academic Publishers.

Webb, J. W., Tihanyi, L., Ireland, R. D., \& Sirmon, D. G. (2009). You say illegal, I say legitimate: entrepreneurship in the informal economy. Academy of Management Review, 34(3), 492-510.

Webb, J., Kistruck, G., Ireland, D., \& Ketchen, D. (2010). The entrepreneurship process in base of the pyramid markets: the case of multinational enterprise/nongovernment organization alliances. Journal of Business Venturing, 34, 555-581.

Williams, C. C. (2008). Beyond necessity-driven versus opportunity-driven entrepreneurship: a study of informal entrepreneurs in England, Russia and Ukraine. International Journal of Entrepreneurship and Innovation, 9(3), 157-165.

Williams, C. C. (2009a). Beyond legitimate entrepreneurship: the prevalence of off-the-books entrepreneurs in Ukraine. Journal of Small Business and Entrepreneurship, 22(1), 55-68.

Williams, C. C. (2009b). The motives of off-the-books entrepreneurs: necessity- or opportunity-driven? International Entrepreneurship and Management Journal, 5(2), 203-217.

Williams, C. C., \& Nadin, S. (2011). Evaluating the nature of the relationship between informal entrepreneurship and the formal economy in rural communities. International Journal of Entrepreneurship and Innovation, 12(2), 95-103.

Williams, C. C., \& Nadin, S. (2012a). Tackling entrepreneurship in the informal economy: evaluating the policy options. Journal of Entrepreneurship and Public Policy, 1(2), 111-124.

Williams, C. C., \& Nadin, S. (2012b). Tackling the hidden enterprise culture: government policies to support the formalization of informal entrepreneurship. Entrepreneurship and Regional Development, 24(9-10), 895-915.

Williams, C. C., \& Nadin, S. (2013). Harnessing the hidden enterprise culture: supporting the formalization of off-the-books business start-ups. Journal of Small Business and Enterprise Development, 20(2), 434-447.

Yang, D. (2011). Migrant remittances. Journal of Economic Perspectives, 25(3), 129-152.

Yeung H. W.-C (2002). Global production networks and foreign direct investment by small and medium enterprises in ASEAN. https://unctad.org/system/files/official-document/diaeia2017d3a1_en.pdf.

Zacharakis, A., McMullen, J., \& Shepherd, D. (2007). Venture capitalists' decision policies across three countries: an institutional theory perspective. Journal of International Business Studies, 38, 691-708.

Zider, B. (1998). How venture capital works. Harvard Business Review. November-December Volume, 131139.

Publisher's Note Springer Nature remains neutral with regard to jurisdictional claims in published maps and institutional affiliations. 


\section{Affiliations}

\section{Eunice Santos ${ }^{1} \cdot$ Cristina I. Fernandes $^{1,2}$ • João J. Ferreira ${ }^{1} \cdot$ Carla Azevedo Lobo $^{3}$}

Eunice Santos

eunicemciliar@gmail.com

João J. Ferreira

jjmf@ubi.pt

Carla Azevedo Lobo

cadsa@upt.pt

1 Department of Management and Economics \& NECE Research Unit in Business Sciences, University of Beira Interior, Covilha, Portugal

2 Centre for Corporate Entrepreneurship and Innovation at Loughborough University, London, UK

3 REMIT-Research on Economics, Management and Information Technologies; IJP-Instituto Jurídico Portucalense, Universidade Portucalense, Porto, Portugal 